\title{
Landforms and rural development: The evolution of human settlements at alpine alluvial fans in the Admont Valley, Austria, since 1784 AD
}

\author{
Andreas KELLERER-PIRKLBAUER ${ }^{1^{*}}$, Julia EULENSTEIN ${ }^{1}$ \\ ${ }^{1}$ Department of Geography and Regional Science, Working Group Alpine Landscape Dynamics \\ (ALADYN), University of Graz, Heinrichstrasse 36, 8010 Graz, Austria; andreas.kellerer@uni-graz.at, \\ julia.eulenstein@uni-graz.at \\ Received 2 December 2019; Revised 7 December 2019; Accepted 9 December 2019 \\ *Correspondence to: Andreas KELLERER-PIRKLBAUER e-mail: andreas.kellerer@uni-graz.at, +43 3163808896
}

\begin{abstract}
We used two historical maps that cover vast areas of central and eastern Europe at rather large scales dating to 1784 (First Military Survey of the Habsburg Empire; total extent $640,000 \mathrm{~km}^{2}$; scale 1: 28,800) and 1824 (cadastral land register of Francis I; $670,000 \mathrm{~km}^{2} ; 1: 2,880$ ) to extract individual buildings located at several alluvial fans in one valley in Austria (Admont Valley). Historic buildings were mapped and compared with present building (airbornelaserscanning based: 2008-2017), geomorphic (landform distribution), geomorphodynamic (documented damaging events at torrents), and spatial planning (hazard zonation maps) data. Results show that $69.2 \%$ of all present buildings are located at only $7 \%$ of the study area. Whereas the 1784-data are too inaccurate and unprecise for detailed spatial analyses, the 1824-data are very accurate and precise allowing spatial and socio-economic insight into the population and building evolution over a 190-year period. Results show for instance that despite a tremendous increase in buildings (911 in 1824; 3,554 in 2008-2017), the proportion of buildings exposed to torrentsrelated natural hazards significantly decreased by $10.4 \%$ for yellow (moderate-risk) and by $13.7 \%$ for red (highrisk) zones. Similar historio-geomorphological studies as presented here might be accomplished in other countries in central and eastern Europe covered by the indicated historical map products.
\end{abstract}

KEYWORDS

Landform-settlement linkage; alluvial fan; natural hazard zonation; Habsburg Empire; historical maps

\section{Introduction}

The initial establishment and evolution of settlements is very often determined by geomorphological conditions and constraints in a given area. Dur- ing periods of settlement foundation, people commonly try to find locations which suit their diversified needs at best. Such needs might be related for instance to agricultural activities (e.g. gentle slopes 
morphologically suitable for agriculture and with sufficient water and nutrient supply, but also with plant-growing favouring local topo-climatic conditions), to strategic considerations (e.g. mountain plateau or summit location for defence reasons and formation of hill-top settlements), to transport infrastructure (e.g. junction of trading routes or the intersection of a trading route with a river crossing in form of a bridge or ford) or to natural-hazard avoidance (e.g. avoiding flood-prone alluvial plains). Particularly in alpine valleys, the issue of naturalhazard avoidance is a very important one. But areas without the risk of being exposed to natural hazards are rare.

Areas prone to landslides, floods, debris floods, debris flows, or snow avalanches reduce the possible settlement area of alpine regions. Thus, people settling in such regions had to decide the lesser of two (or even more) evils such as annual floods at alluvial plains versus occasional debris flows or floods from torrents at alluvial fans. Alluvial plains of large, meandering rivers in alpine valleys of Austria, for instance, were mainly avoided, because of moreor-less regular spring floods during the snow-melt period inundating the plains. Thus, people settled and reclaimed land more commonly at alluvial fans adjacent to the alluvial plains which were formed by tributary creeks. Damaging events such as debris flows or floods also occurred on fans, but not on an annual basis. People were surely aware of the threat of potential natural hazard events at alluvial fans. Patzelt (1987) for instance studied the evolution of alluvial fans in western Austria at a Holocene-time scale, revealing that sediment accumulation prevails in a sequence of sediment accumulation, erosion and stagnation. According to Patzelt, periods of accumulation correlate with periods of climatic deterioration (e.g. the Little Ice Age) inferred from the development of vegetation and glaciers. Based mainly on archaeological excavations, Zanesco et al. (2008) report from massive sedimentation at the alluvial fan of Hall in Tyrol (Fig. 2) where more than two meters of sediments were deposited during one single flooding event in the year 1275 AD. This suggests the importance of high-magnitude but lowfrequency events for geomorphic changes at (settled) alluvial fans.
Archaeological research at alluvial fans also helps to understand the long-term relationship between settlement and fan evolution. Excavations at the ancient town of Aguntum (Figs. 1, 3), the only antique city in the Austrian province of Tyrol, revealed a substantial surface elevation increase during the c. 500 years of building activities. Aguntum was founded at the alluvial fan of an alpine torrent named Debant Creek. Figure 1 illustrates parts of the city with the eastern city wall as well as surface elevation change markers during the settlement period ( $1^{\text {st }}$ to $6^{\text {th }}$ century $A D$ ) as it is presented to modern visitors of this roman settlement site. The depicted stepwise rise of the surface over time must be seen in a schematic way. The reason for the raising of the terrain between c.100 and 400 AD was according to archaeologists - mainly artificial filling by the Romans and only to a minor extent by natural sources such as debris-charged floods. Unterweger (2018) suggests that the inhabitants of Aguntum protected their settlement by water protection constructions diverting the water course of the Debant Creek to the west and thus letting it pass the city of Aguntum at its western periphery. After the city was abandoned, the creek reclaimed its alluvial fan and moved towards the central part of Aguntum. This partly covered the ancient surface with a complex debris layer resulting from repeated flooding events and with a thickness of up to three meters (Auer, 2013; Unterweger, 2018).

The growth of settlements in higher-elevated zones of alpine areas - as the European Alps - was slow in historical times as pointed out by Slaymaker and Embleton-Hamann (2009). This contrasts with the bottoms of the main valleys with their large alluvial fans. At the valley bottoms and particularly at alluvial fans, a strong population growth occurred with a continuous trend over the past 150 years (Slaymaker and Embleton-Hamann, 2009). Such an increase in population and thus housing development over time is not always straightforward to bring into a temporal-spatial dimension due to lacking or only poor-quality maps.

The increased availability of historic maps with a reasonable scale and accuracy in digital formats, allows to perform long-term (in our case >200 years) studies related to settlement evolution. In the 
present study we aimed to quantify and illustrate the settlement evolution of a historically important valley in alpine Austria, focussing on one landform type, namely alluvial fan. More specifically, the aims of this paper are to (a) compare the spatial pattern and distribution of buildings and settlements at eight alluvial fans in the Admont Valley (cf. Fig. 1) between the early period of official land mapping at rather large scale in $1784(1: 28,800)$, in 1824 $(1: 2,880)$ and today $(1: 500)$, and to combine this information with (b) present-day hazard-zone plans as well as with (c) documented damaging natural hazard events, and finally (d) to discuss these relationships in a broader historio-geomorphological context.

\section{Study area}

The study area named Admont Valley is a ca. $20 \mathrm{~km}$ long valley segment of the Enns valley, and its surrounding mountains in central Austria (Fig. 2). The Admont Valley was first mentioned in written sources in 859 AD as Adamundi valle (List, 1974). One interpretation of this name is that it originally comes from the Latin word ad monte meaning near the mountains. In 1074 AD, a Benedictine abbey was founded in this valley (Wichner, 1880). As passed on by a legend, the originally selected location of the abbey north of the Enns River near its riverbank was prone to floods and snow avalanches (Krause, 1966). Thus, the archbishop of Salzburg decided to establish the abbey at the lower part of an alluvial fan formed by the Lichtmessbach torrent, south of the Enns River (Fig. 3a). The torrent originates from further to the south (named Kaiseraubach there) and flows through easily erodible phyllitic rocks. The torrent repeatedly harmed the settlement of Admont, which eventually led to the construction of a large retention dam in 2013-2015 in the upper section named Kaiserau (Fig. 3a).

The Enns valley at Admont is morphologically dominated by a broad alluvial plain with distinct meander loops partly filled by oxbow lakes. As depicted by the historical maps listed further below and recent airborne laser scanning (ALS) data, the meandering Enns River in the Admont Valley changed the course substantially over time - at least until the mid- $19^{\text {th }}$ century. In the $19^{\text {th }}$ century, water regulation measures modified the channel course and lowered the water level of the Enns River by several meters (Reismann et al., 2015).

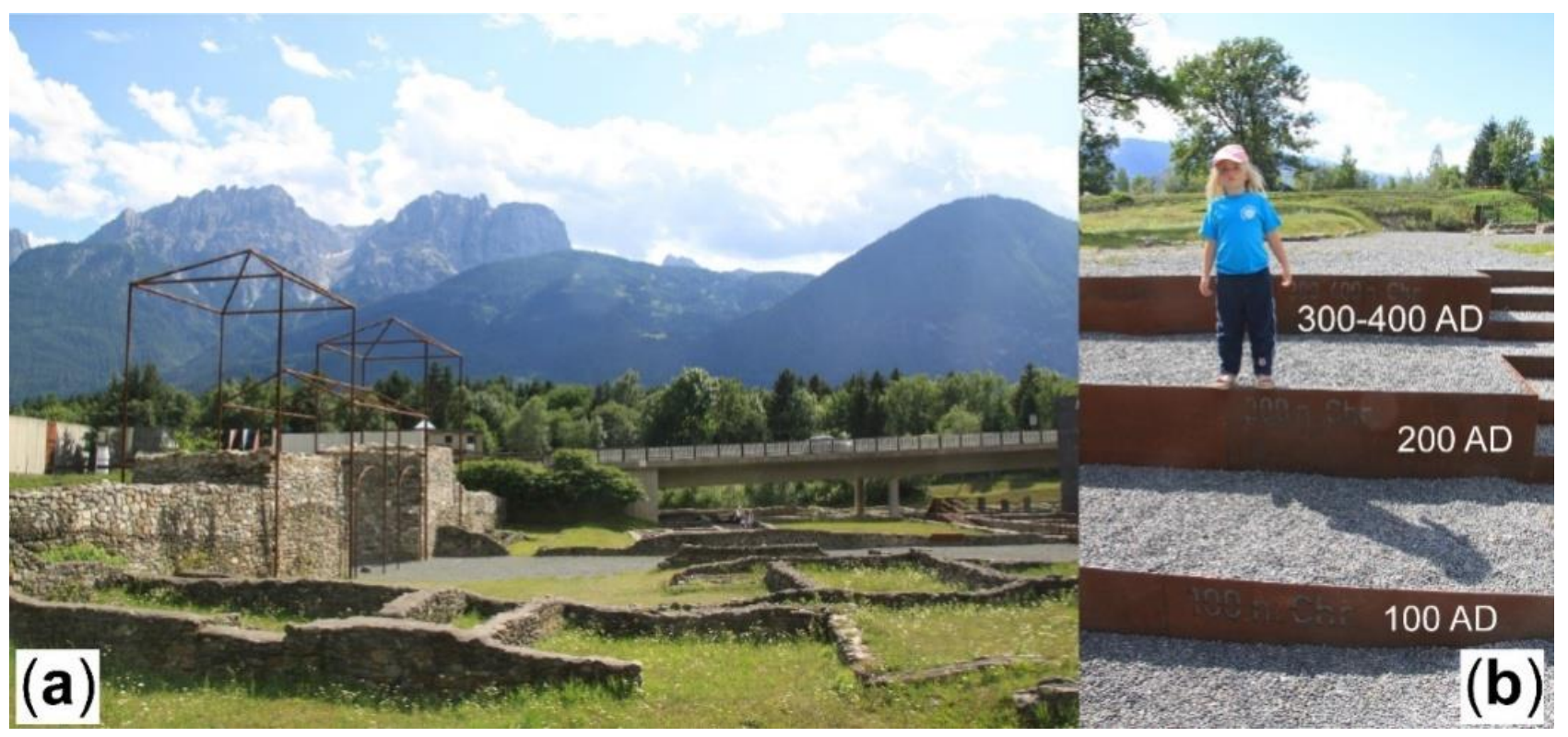

Figure 1 Ruins of the former roman settlement of Aguntum in western Austria built on the alluvial fan of the Debant Creek. (a) Overview map of the archaeological site with the city gate and city wall to the left; (b) schematic chronological evolution of the increase of surface elevation over time between ca. 100 and 400 AD. Source of photos: authors. For location, see Fig. 2 


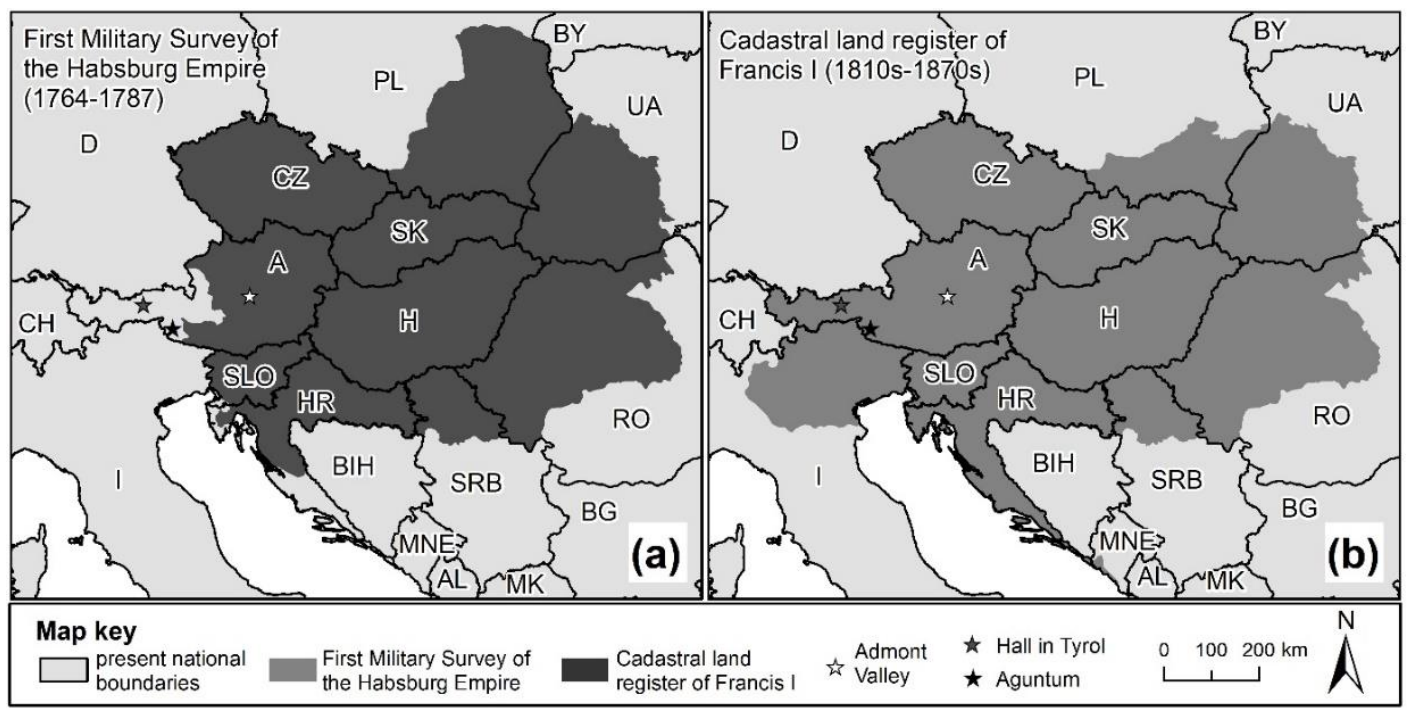

Figure 2 Location of the study area Admont Valley in Austria and its spatial relationships to the (a) First Military Survey of the Habsburg Empire (1764-1787) - excluding present-day Belgium - as well as the (b) cadastral land register of Francis I

(1810s-1870s). Two settlements located on alluvial fans mentioned in the text are indicated. Data base for (a) is Hofstätter (1989) and mapire (https://mapire.eu/en); data base for (b) is Fuhrmann (2007)

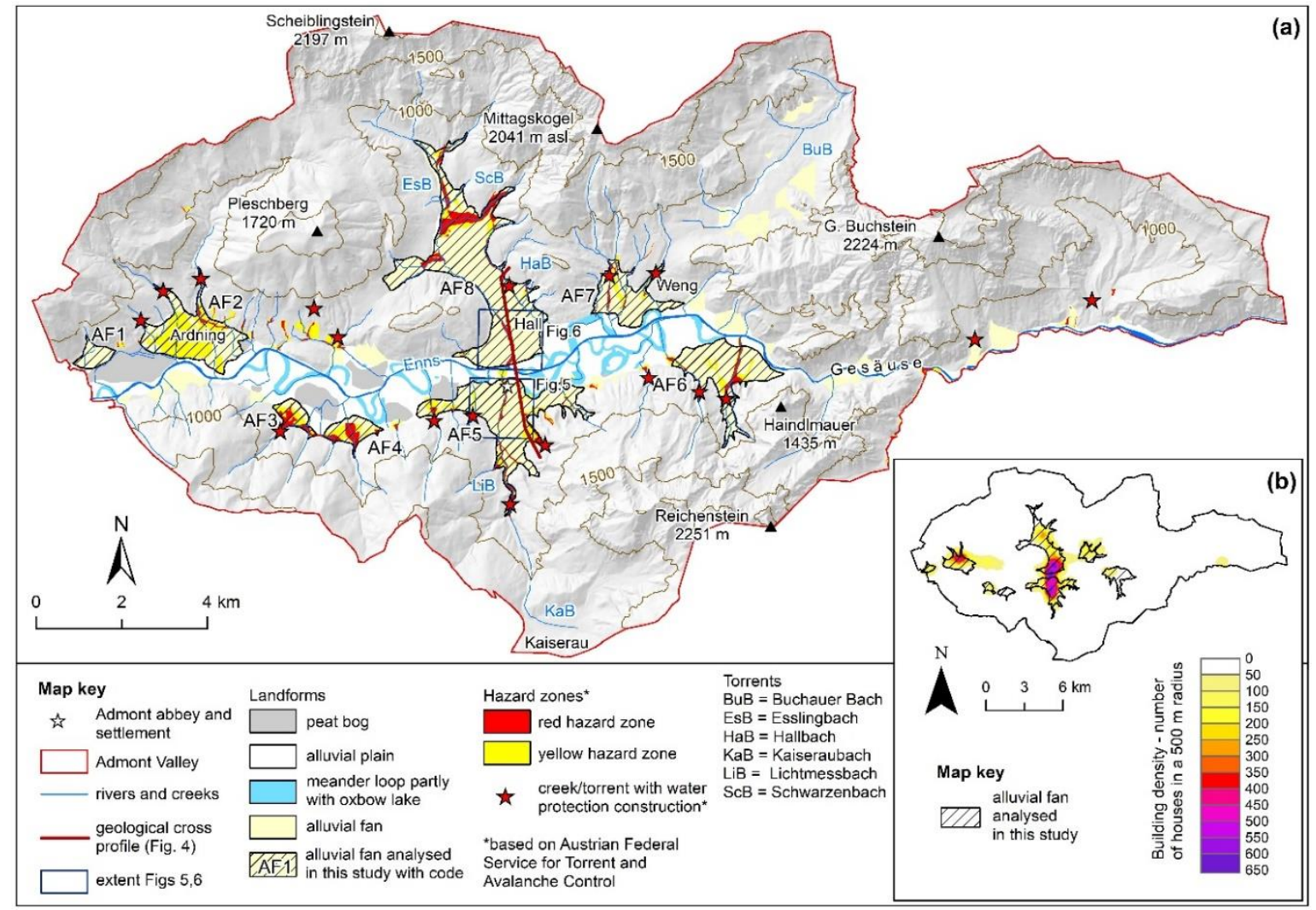

Figure 3 Study area Admont Valley: (a) overview map with the location and extent of the eight studied alluvial fans (AF18), relevant fluvial landforms as well as the spatial extent of yellow (moderate-risk) and red (high risk) hazard zones along torrents (mostly with protection constructions) as defined by the hazard-zone maps of the Austrian Federal Service for Torrent and Avalanche Control (zonation based on Federal Ministry for Sustainability and Tourism 2017). (b) Building density in the Admont Valley in relation to the eight studied alluvial fans (building data taken from Land Steiermark 
Topographically connected and sedimentologically interlocked with the alluvial plain are the numerous alluvial fans on both valley sides. Two large fans (AF5, AF6 in Fig. 3a) are at the southern side and further three large ones are on the northern side (AF2, AF7, AF8). The reason for the existence of the alluvial plain is that the valley east of alluvial fan AF6 is narrowing. There, the Enns River enters a gorge named Gesäuse attributed to the noisemaking cataracts of the Enns River. Repeated massmovement events during the Lateglacial and Holocene period at the western end of this narrowing called Haindlmauer (Büchner, 1974) caused backwaters of the Enns River leading to the formation of temporal lakes with related sedimentation (alternating strata of pebbles, sand, silt and peat) as indicated by drillings (cf. Fig. 4).

The main landforms of interest with their settlement evolutions are eight alluvial fans covering a total area of $16.6 \mathrm{~km}^{2}$, which is $7 \%$ of the entire Admont Valley $\left(236.1 \mathrm{~km}^{2}\right)$. Table 1 lists names, codes used in this study and areal extent of the eight fans. As indicated by the building-density map in Figure $3 \mathrm{~b}$, by far most of the present buildings in the Admont Valley $(n=5135$; see further below for data source) are located at the eight alluvial fans $(n=3554$; i.e. $69.2 \%)$ highlighting the importance of alluvial fans for settlement evolution.

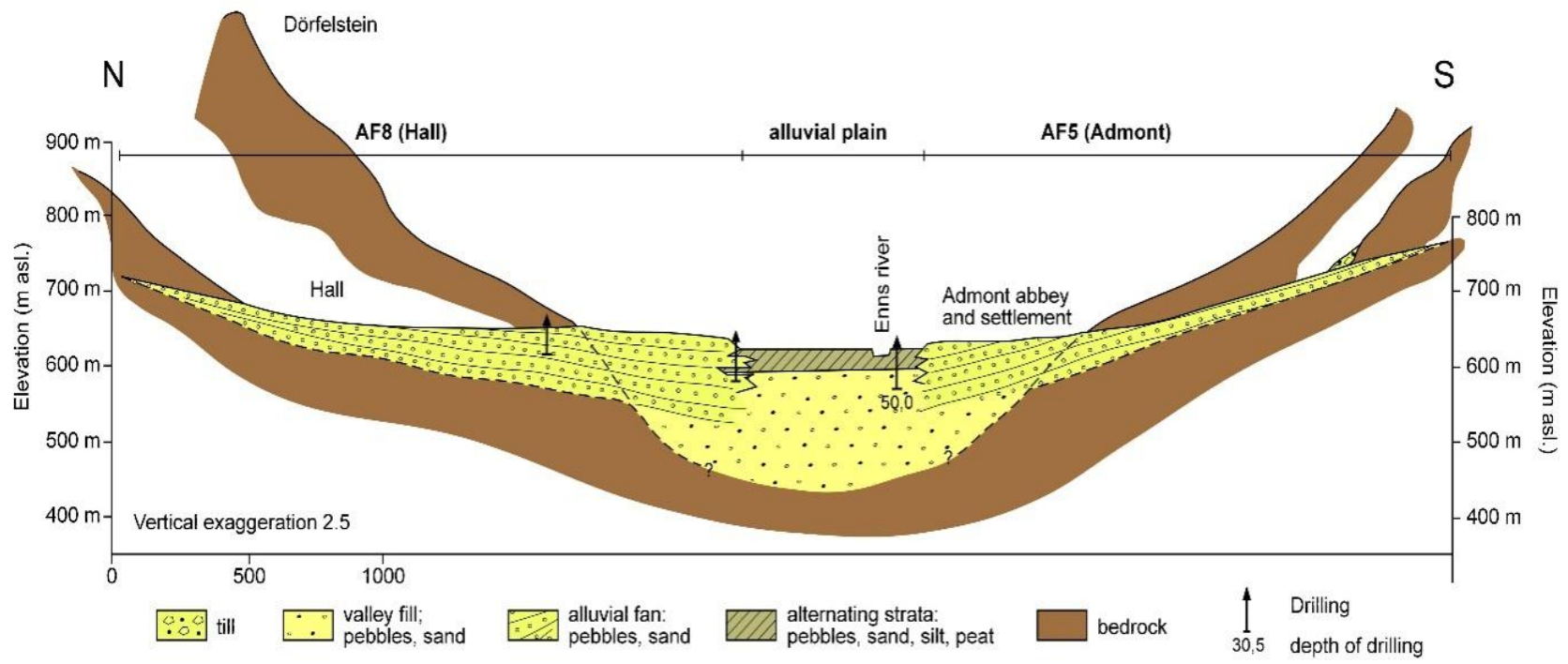

Figure 4 Geological cross profile through the Admont Valley from north to south crossing the two large alluvial fans at Admont (AF5) and Hall (AF8). Note the interlocked sedimentary structure in the valley bottom related to the repeated damming of the Admont Valley by mass movements further east (data source: Kellerer-Pirklbauer et al., 2004, modified)

Table 1 The eight studied alluvial fans (AF) in the Admont Valley listing codes, total area of the alluvial fans as well as their shares $\left(\mathrm{km}^{2}\right)$ and percentages, respectively, considered by yellow (moderate-risk) and red (high-risk) hazard zones (cf. Fig. 3)

\begin{tabular}{l|l|ccccc|cccc}
\hline Code & Name & \multicolumn{4}{|c|}{ Area $\left(\mathrm{km}^{2}\right)$} & \multicolumn{4}{c}{ Area (\%) } \\
\cline { 3 - 10 } & & total & \multicolumn{4}{c|}{ hazard zone } & \multicolumn{4}{c}{ hazard zone } \\
AF1 & Pürgschachen & 0.37 & 0.00 & 0.00 & 0.00 & 0.37 & 0.0 & 0.0 & 0.0 & 100.0 \\
AF2 & Ardning & 2.36 & 1.25 & 0.11 & 1.36 & 1.01 & 52.7 & 4.7 & 57.4 & 42.6 \\
AF3 & Dörfler Siedlung & 0.43 & 0.14 & 0.14 & 0.28 & 0.15 & 33.2 & 33.0 & 66.2 & 33.8 \\
AF4 & Treffner & 0.57 & 0.15 & 0.17 & 0.32 & 0.25 & 26.7 & 29.7 & 56.4 & 43.6 \\
AF5 & Admont & 3.41 & 0.43 & 0.31 & 0.74 & 2.68 & 12.5 & 9.1 & 21.6 & 78.4 \\
AF6 & Krumau & 2.15 & 0.19 & 0.12 & 0.31 & 1.85 & 8.9 & 5.4 & 14.3 & 85.7 \\
AF7 & Weng & 1.41 & 0.19 & 0.11 & 0.30 & 1.11 & 13.3 & 7.8 & 21.1 & 78.9 \\
AF8 & Hall & 5.94 & 0.33 & 0.72 & 1.05 & 4.88 & 5.6 & 12.2 & 17.8 & 82.2 \\
AII & & 16.64 & 2.68 & 1.68 & 4.36 & 12.28 & 16.1 & 10.1 & 26.2 & 73.8 \\
\hline
\end{tabular}




\section{Material and Methods}

\subsection{Historical maps: 1784 and 1824}

A substantial improvement of the quality of maps of Central Europe was the First Military Survey of the Habsburg Empire carried out between 1764 and 1787 (Hofstätter, 1989). The First Military Survey of the Habsburg Empire (or Josephinische Landesaufnahme) was initiated by the order of Empress Maria Theresia in the 1760s and finalised more than two decades later during the reign of Emperor Josef II. Decisive for this survey were military interests related to the disadvantages of the Austrian army during the Seven Years' War in 1756-1763. The scale of the survey sheets (about 4,000) was 1:28,800. The survey had neither a triangulation basis, nor clearly defined projection (Hofstätter, 1989) impacting severely georeferencing procedures (Mólnar et al., 2014). Figure 2a depicts the spatial extent of the First Military Survey of the Habsburg Empire - excluding present-day Belgium - covering about $640,000 \mathrm{~km}^{2}$.

During the First Military Survey of the Habsburg Empire in the period 1764-1787, the Admont Valley belonged to the administration unit Innerösterreich (Hofstätter, 1989). This part of the former Habsburg Empire was surveyed in 1784-1785 (for simplicity hereafter considered as 1784). The sheets from this survey are nowadays available online (digital access https://mapire.eu/en) even as georeferenced products with a rather good geometric accuracy (Mólnar et al. 2014). For the present study we had access to a georeferenced map of the First Military Survey computed by the Federal Government of Styria. Furthermore, we also used the relevant maps from Mapire for accuracy-assessment reasons. At Mapire, we exported the relevant map sections from their website and georeferenced them in ArcGIS 10.5. Suitable objects for georeferencing were churches (Weng, Ardning, and Hall), historical buildings (Admont Abbey) and bridges which still exist today and where the building geometry in the historical map seemed comparable to the one of today. The georeferencing procedure was enabled by using high resolution terrain data $(1 \mathrm{~m}$ digital elevation model based on air-borne laserscanning data) provided by the Federal Government of Styria, freely available optical remote sensing data (ArcGIS base data) and the open street map.

The First Military Survey was followed by the substantially improved Second Military Survey of the Habsburg Empire (or Franziszeische Landesaufnahme) in 1808-1869 and the Third Military Survey of the Habsburg (or Franzisco-JosephinischeLandesaufnahme) in 1869-1887 (Hofstätter, 1989). An important further development during the Habsburg Empire was the detailed mapping and development of the cadastral land register of Francis I (Franziszeischer Kataster or Stabiler Kataster) accomplished between 1817 and 1861 (Fuhrmann, 2007). The scale of the cadastral land register was (apart from alpine and urban areas) 1:2,880 consisting of more than 53,200 sheets covering a total area of about $670,000 \mathrm{~km}^{2}$ (Fig. 2b).

The survey for the cadastral land register of Francis I in the Admont Valley was performed in 1824. The data from this survey were also taken from Mapire (digital access https://mapire.eu/en) where we exported the relevant sections from the website and georeferenced them in ArcGIS 10.5 using the same remote sensing data as indicated above. Suitable objects for georeferencing were again churches, historical buildings, and bridges.

After georeferencing both historical maps (1784 and 1824), we digitised the spatial geometry of buildings that were located during those times at one of the eight alluvial fans. The accuracy of the georeferencing procedure for the cadastral land register of Francis I (scale 1:2,880) was high with about $10 \mathrm{~m}$ as judged form georeferencing quality control checks. The accuracy of the georeferenced maps of the First Military Survey of the Habsburg Empire is, however, much poorer due to the distortion of the map related to triangulation and projection problems (Mólnar et al., 2014) but also due to the substantially smaller scale $(1: 28,800)$.

\subsection{Further data sources and data analyses}

A high-resolution terrain model with a $1 \mathrm{~m}$ resolution (provided by the Federal Government of Styria) derived from ALS-data and freely available optical remote sensing data were used to map the different landforms in the Admont Valley focusing particularly on alluvial fans. Based on ALS data primarily 
Landforms and rural development:

The evolution of human settlements at alpine alluvial fans in the Admont Valley, Austria, since 1784 AD

dating to 2008-2012 and occasionally to 2017 (for simplicity hereafter considered as 2008-2017), the Federal Government of Styria extracted the geometry of all buildings in the federal province of Styria mapped at scale 1:500. This dataset comprises 5135 buildings for the Admont Valley, $69.2 \%$ of them $(n=3554)$ are located on one of the eight studied alluvial fans (Land Steiermark, 2019). The building density for the Admont Valley (Fig. 3b) was calculated using these data and the point density function (with $10 \mathrm{~m}$ grid size, $500 \mathrm{~m}$ radius) in ArcGIS.

Table 2 Documented damaging events at the eight studied alluvial fans (AF) in the Admont Valley in 1851-2017 distinguished between floods (flood), fluvial sediment transport events (notable but $<20 \%$ volumetric debris content; flu-se), debris floods (20-<40\% debris content; de-flood), debris flows (>40\% debris content; de-flow), landslides (landsl) and snow avalanches (avala). Data taken form WLK 2019

\begin{tabular}{l|lllllll}
\hline Code & flood & flu-se & de-flood & de-flow & landsl & avala & sum \\
\hline AF1 & 0 & 0 & 0 & 0 & 0 & 0 & 0 \\
AF2 & 7 & 7 & 1 & 2 & 0 & 2 & 19 \\
AF3 & 0 & 0 & 0 & 1 & 0 & 0 & 1 \\
AF4 & 0 & 0 & 0 & 0 & 0 & 0 & 0 \\
AF5 & 3 & 0 & 0 & 4 & 1 & 0 & 8 \\
AF6 & 0 & 10 & 0 & 0 & 0 & 1 & 11 \\
AF7 & 3 & 5 & 2 & 0 & 0 & 0 & 10 \\
AF8 & 6 & 4 & 0 & 0 & 0 & 0 & 10 \\
all & 19 & 26 & 3 & 7 & 1 & 3 & 59 \\
\hline
\end{tabular}

Data about the population evolution between 1869 and 2018 in the study area were taken from Statistik Austria (2019). The Austrian Federal Service for Torrent and Avalanche Control (WLV) provided digital hazard zonation maps that define yellow and red hazard zones for torrents and avalanche areas (Federal Ministry for Sustainability and Tourism, 2017). The delineation of these hazard zones in the Admont Valley was accomplished in the period 19812015. Red hazard zones indicate areas where construction of new houses is prohibited (high-risk zones). Yellow hazard zones define areas where significant damage to properties or infrastructure must be expected and therefore construction is restricted (moderate-risk zones).

The WLV also provided data regarding flood and debris-flow protection structures (pers. comm. Markus Mayerl) for this study. Finally, damaging events related to snow and water processes in the Admont Valley were also kindly provided by the WLV containing the period 1851-2017 (WLK, 2019). Spatial analyses were accomplished in ArcGIS. Statistical analyses were performed in Excel and SPSS.

\section{Results}

\subsection{Alluvial fans and natural hazards related to torrents}

The eight studied alluvial fans in the Admont Valley vary in size from 0.37 to $5.94 \mathrm{~km}^{2}$ summing up to $16.64 \mathrm{~km}^{2}$ (Table 1). About $26 \%$ of this area is considered in modern hazard zonation plans; $16 \%$ of it is in yellow hazard zones and $10 \%$ in red hazard zones. As depicted in Figure 3 and summarized in Table 1, the relative proportions of the two hazard zone types at the eight different alluvial fans vary substantially. No hazard zones are designated at AF1 related to a (building-sheltering) road construction (highway A9/E57) at the upper part of the fan. About $57 \%$ of AF2 are either classified as yellow $(52.7 \%)$ or red hazard zone $(4.7 \%)$ even though water protection structures were built at three torrents flowing onto the fan. AF3 and AF4 are of similar size and similarily considered by hazard zones. The relative shares of red and yellow zones at the two fans AF5 and AF7 is similar with $21 \%$ in both cases. At AF6 hazard zones are by one third less important regarding relative proportion. Finally, at the very lar- 
ge alluvial fan AF8 (36\% of the entire study area) red zones are extended along the Schwarzenbach and Esslingbach torrents. However, the total relative share regarding hazard zones at this fan is moderate with $18 \%$.

Altogether, 95 damaging events related to snow and water were inventoried by the Austrian Federal Service for Torrent and Avalanche Control (WLK, 2019) for the period 1851-2017 in the Admont Valley. Most of the 95 events occurred along creeks and torrents all over the Admont Valley. 59 out of these 95 events (62\%) occurred on the eight alluvial fans, by far most of them at AF2 (19) followed by AF6-8 (10-11 events). The Lichtmessbach for instance caused damaging floods $(1897,1951)$ and debris flows $(1851,1885,1949)$ at the AF5. Regarding process types, most importantly are fluvial sediment transport events (26) and floods (19) followed by debris flows (7). These results imply that the largest and most-populated alluvial fans are also the ones which experienced most damaging events in the past. It is the question if this result reveals the natural circumstances or if it originates in the fact that only the incidences that caused damage to human infrastructure were noted. Without further field analysis this question cannot be answered.

\subsection{Building structure in $\mathbf{1 7 8 4}$}

199 buildings were mapped at the eight studied alluvial fans for 1784. By far most of the buildings were delineated at AF8 (81) followed by AF5 (38) and AF2 (30). Table $3 a$ lists the number of houses at the eight alluvial fans and their spatial relationship to yellow and red hazard zones. The table contains furthermore the spatial extent and some spatial statistics for all mapped buildings for 1784 . The average size of all mapped 199 building is $1074 \mathrm{~m}^{2}$. The buildings ranged from 271 to $15,953 \mathrm{~m}^{2}$ in size. Figures $5 \mathrm{a}$ and $6 \mathrm{a}$ show exemplarily the mapping results of sub-areas AF5 and AF8. As depicted, the buildings look generalized attributed mainly to the original map scale of $1: 28,800$. The four largest buildings in 1784 are all at AF5 also shown in Figure $5 a$. The third-largest building is the Benedictine Abbey of Admont, presented as a U-shaped polygon; the other three are elongated blocks. Figure 7a distinguishes graphically the number of buildings per alluvial fan located within or outside hazard zones. $29 \%$ of the buildings were partly or entirely in a present-day red zone area whereas $41 \%$ would have been within a yellow-zone area. Figure 8 presents the relative shares of the studied alluvial fans covered by buildings during the three different stages. Results show that the relative shares of the alluvial fans covered by buildings varied in 1784 between 0.5 (AF4) and $2.3 \%$ (AF5) averaging to $1.3 \%$ of the total area. In absolute numbers, this is $0.21 \mathrm{~km}^{2}$ of the $16.61 \mathrm{~km}^{2}$ large study area.

\subsection{Building structure in $\mathbf{1 8 2 4}$}

For the year 1824 altogether 911 buildings were mapped at the eight alluvial fans. At this stage different to 1784 - most of the buildings were delineated at AF5 (303) followed by AF8 (282) slightly behind (Table $3 b$ ). Table $3 b$ contains the spatial extent and spatial statistics for all mapped buildings from this year. The average size of all 911 buildings is $164 \mathrm{~m}^{2}$ and hence only about $15 \%$ of the mean building size mapped in 1784 . The buildings in 1824 ranged from only 6 (much smaller than in 1784) to $14,977 \mathrm{~m}^{2}$ (like 1784) in size. The smallest buildings were often barns distributed over the agricultural land. Figures $5 b$ and $6 b$ show selected mapping results for parts of AF5 and AF6. As depicted, the building structure is substantially different and much more detailed compared to the previous stage 1784 attributed also to the 10-times larger scale of the original maps. The by far largest building in the entire study area was at that time the building-complex of the abbey in Admont (14,977 $\mathrm{m}^{2}$ ). The second-largest building (also at AF5) only covered $3625 \mathrm{~m}^{2}$. Figure $7 \mathrm{~b}$ distinguishes graphically the number of buildings per alluvial fan located within or outside different hazard zones. 233 (26\%) of the altogether 911 buildings were partly or entirely in a present-day red zone area whereas 335 of the buildings (37\%) would have been within a modern-day yellow-zone area. At an alluvial fanscale, these figures are even more dramatic for AF3 and AF5 (Table 3b). Figure 8 shows that the relative shares of the studied alluvial fans covered by buildings in 1824 where on average $31 \%$ less compared to 1784 . 
Landforms and rural development:

The evolution of human settlements at alpine alluvial fans in the Admont Valley, Austria, since 1784 AD

For 1824, results show that the relative shares of the alluvial fans covered by buildings varied between
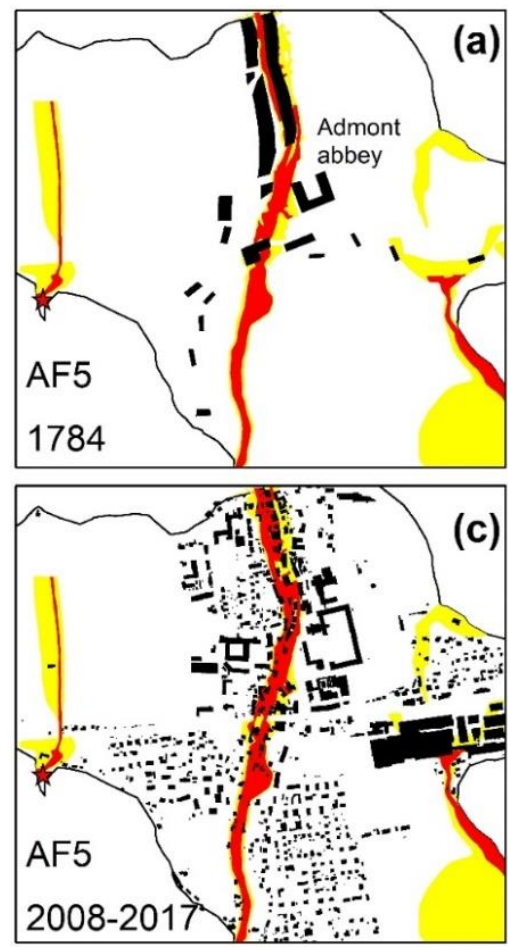

only 0.3 (AF6) and $2.0 \%$ (AF5) averaging to $0.9 \%$ of the total area, which is $0.15 \mathrm{~km}^{2}$.
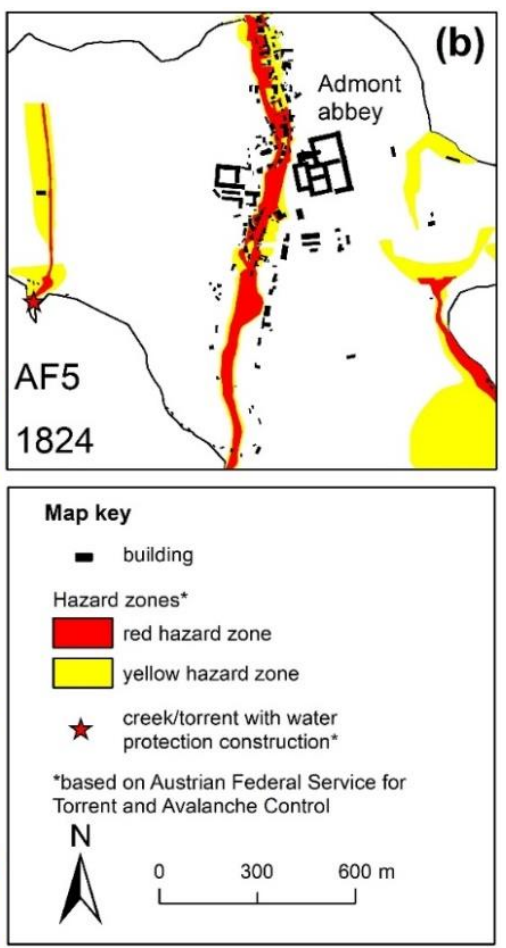

Figure 5 Spatial building distribution at the central part of alluvial fan AF5 (Admont) in 1784 (a), in 1824 (b) and in the time period 2008-2017 (c) in relation to the present hazard zonation (for location see Fig. 3a)
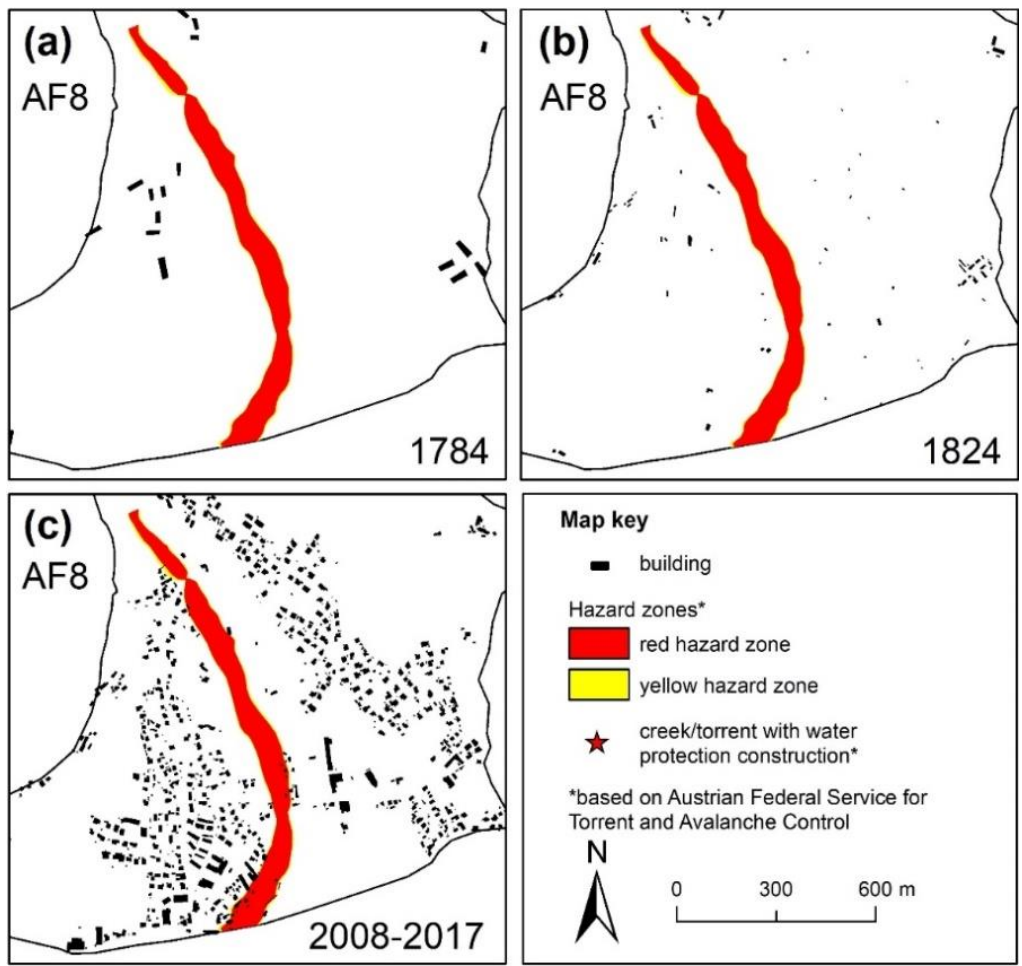

Figure 6 Spatial building distribution at the central part of alluvial fan AF8 (Hall) in 1784 (a), in 1824 (b) and in the time period 2008-2017 (c) in relation to the present hazard zonation (for location see Fig. 3a) 
Table 3 Number of buildings and related spatial statistical parameters at the eight studied alluvial fans in the Admont Valley in 1784 based on historical maps (a), 1824 based on historical cadastral data (b), and today based on

ALS-Data (c)

\begin{tabular}{|c|c|c|c|c|c|c|c|c|}
\hline \multirow[t]{3}{*}{ Code } & \multicolumn{7}{|c|}{ Buildings } & \multirow{2}{*}{$\begin{array}{l}\text { Percentage of } \\
\text { alluvial fan cov- } \\
\text { ered by buildings } \\
(\%)\end{array}$} \\
\hline & \multirow[t]{2}{*}{$\begin{array}{l}\text { number } \\
\text { (n) }\end{array}$} & \multicolumn{2}{|c|}{$\begin{array}{l}\text { entirely or partly in } \\
\text { hazard zone: }\end{array}$} & \multicolumn{3}{|c|}{ area $\left(m^{2}\right)$} & & \\
\hline & & red & yellow & sum & $\min$. & $\max$ & mean & total \\
\hline \multicolumn{9}{|c|}{ (a) 1784} \\
\hline AF1 & 8 & 0 & 0 & 8229 & 809 & 1496 & 1029 & 2.3 \\
\hline AF2 & 30 & 17 & 21 & 26212 & 398 & 2750 & 874 & 1.1 \\
\hline AF3 & 5 & 2 & 4 & 6522 & 1066 & 1756 & 1304 & 1.5 \\
\hline AF4 & 5 & 0 & 1 & 3058 & 461 & 926 & 612 & 0.5 \\
\hline AF5 & 38 & 14 & 19 & 78457 & 435 & 15953 & 2065 & 2.3 \\
\hline AF6 & 15 & 0 & 3 & 11908 & 447 & 1476 & 794 & 0.6 \\
\hline AF7 & 17 & 8 & 13 & 24212 & 317 & 3387 & 1424 & 1.7 \\
\hline AF8 & 81 & 16 & 20 & 55138 & 271 & 1291 & 681 & 0.9 \\
\hline all & 199 & 57 & 81 & 213736 & 271 & 15953 & 1074 & 1.3 \\
\hline
\end{tabular}

\begin{tabular}{lllllllll}
\hline (b) 1824 & & & & & & \\
AF1 & 30 & 0 & 0 & 2818 & 23 & 197 & 94 & 0.8 \\
AF2 & 93 & 13 & 58 & 16187 & 19 & 686 & 174 & 0.7 \\
AF3 & 32 & 21 & 18 & 3095 & 21 & 277 & 97 & 0.7 \\
AF4 & 31 & 8 & 12 & 4707 & 21 & 1019 & 152 & 0.8 \\
AF5 & 303 & 108 & 130 & 67903 & 6 & 14977 & 224 & 2.0 \\
AF6 & 52 & 0 & 10 & 6794 & 7 & 566 & 128 & 0.3 \\
AF7 & 88 & 24 & 47 & 15222 & 15 & 1260 & 173 & 1.1 \\
AF8 & 282 & 59 & 60 & 32336 & 10 & 861 & 115 & 0.5 \\
all & 911 & 233 & 335 & 149062 & 6 & 14977 & 164 & 0.9 \\
\hline (c) 2008-2017 & & & & & & & \\
AF1 & 104 & 0 & 0 & 13827 & 6 & 769 & 133 & 3.8 \\
AF2 & 502 & 79 & 364 & 84086 & 6 & 3083 & 168 & 3.6 \\
AF3 & 77 & 23 & 54 & 6786 & 7 & 529 & 88 & 1.6 \\
AF4 & 24 & 5 & 7 & 2937 & 8 & 683 & 122 & 0.5 \\
AF5 & 1126 & 147 & 243 & 256047 & 6 & 31137 & 227 & 7.5 \\
AF6 & 93 & 3 & 15 & 11136 & 7 & 700 & 120 & 0.5 \\
AF7 & 235 & 41 & 119 & 55512 & 6 & 5374 & 236 & 3.9 \\
AF8 & 1393 & 125 & 137 & 207279 & 4 & 1841 & 149 & 3.5 \\
all & 3554 & 423 & 939 & 637610 & 4 & 31137 & 179 & 3.8 \\
\hline
\end{tabular}

\subsection{Building structure in 2008-2017}

For the most recent of the three analysed stages, a total number of 3,554 buildings were counted at the eight alluvial fans (Table 3c). This value is about 4 times higher than 190 years earlier. $71 \%$ of all buildings are located at the two alluvial fans AF5 (Admont) and AF8 (Hall). This massive increase in buildings since 1824 is also well illustrated in Figures $5 \mathrm{c}$ (for AF5) and $6 \mathrm{c}$ (for AF8). Most buildings were counted for the last stage at the alluvial fan in Hall (AF8; 1393 buildings) followed by the one in Ad- mont (AF5; 1126). The third most important alluvial fan for settlement in the Admont Valley is - although far behind the other two - the one in Ardning (AF2; 502). Table $3 \mathrm{c}$ lists the number of houses at the eight alluvial fans, their spatial relationships to yellow and red hazard zones and areal information about building-extend conditions. The average size of all 3,554 buildings is $179 \mathrm{~m}^{2}$ which is only $9 \%$ larger than 190 years earlier. The buildings range from 4 to $31,137 \mathrm{~m}^{2}$ in size. 
Landforms and rural development:

The evolution of human settlements at alpine alluvial fans in the Admont Valley, Austria, since 1784 AD
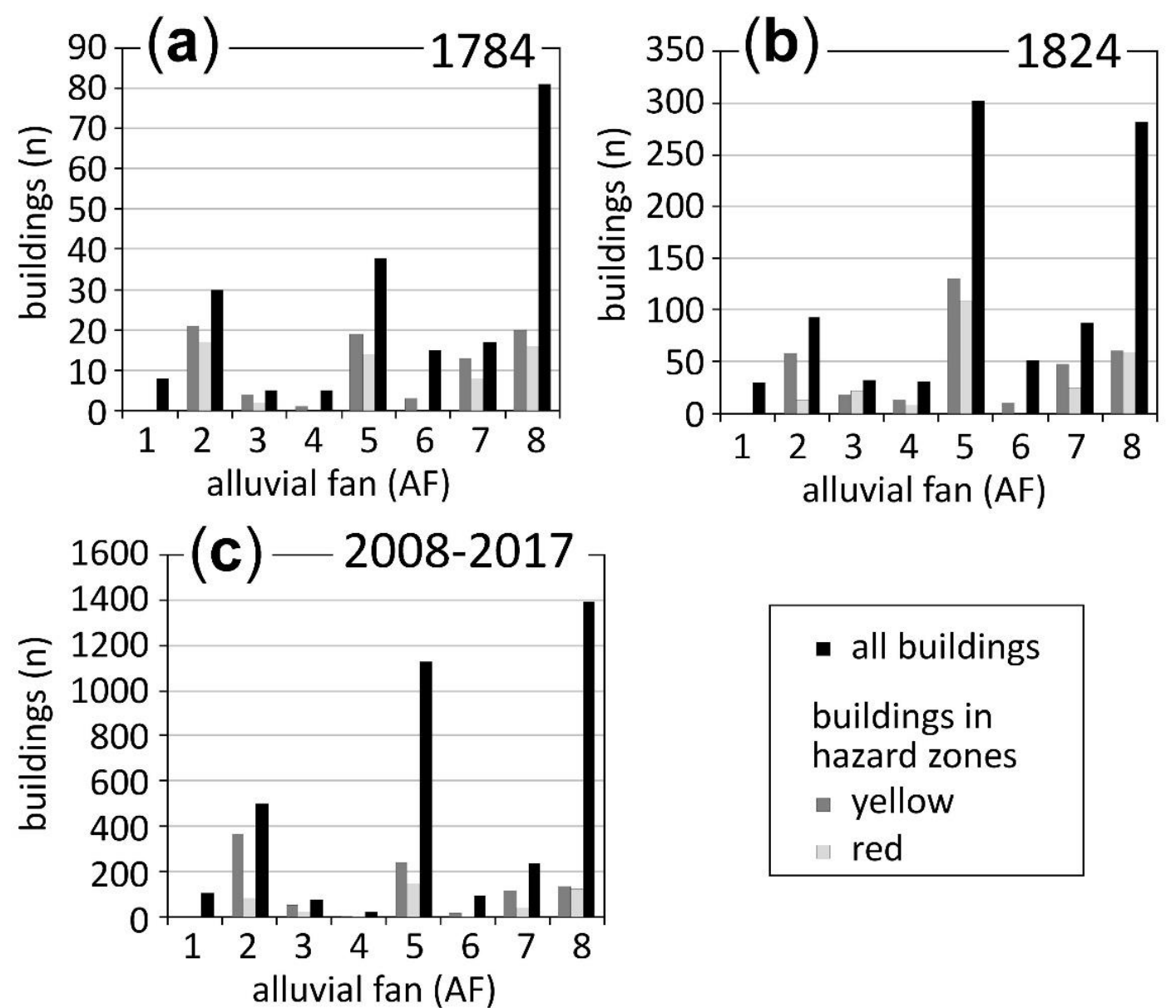

- all buildings

buildings in hazard zones

- yellow

red

Figure 7 Number of buildings at the eight studied alluvial fans in 1784 (a), in 1824 (b) and in the time period 2008-2017 (c) and their relationship to the present hazard zonation plans (cf. Fig. 3). Considered buildings in the hazard zones are either entirely or partly in the indicated hazard zones. Note the different scale in the axis of ordinates

However, a high number of small but also one very large building (for wood industry; 31,137 $\mathrm{m}^{2}$ ) were added. The main building of the Admont Abbey covers $13,105 \mathrm{~m}^{2}$ (=second largest building) which is $12 \%$ less compared to 1824 . Figure $7 \mathrm{c}$ distinguishes graphically the number of buildings per alluvial fan located within or outside hazard zones. Only $12 \%$ of the buildings are partly or entirely in present-day red zones whereas $26 \%$ are partly or entirely in a yellow-zone area.

Figure 8 shows that the relative shares of the alluvial fans covered by buildings vary at present between 0.5 (AF4 and AF6) and 7.5\% (AF5) averaging to $3.8 \%$ of the total area which is 4.2 times (or 0.49 $\mathrm{km}^{2}$ ) more compared to 1824 . In absolute numbers, some $0.64 \mathrm{~km}^{2}$ of the study area is covered by buildings.

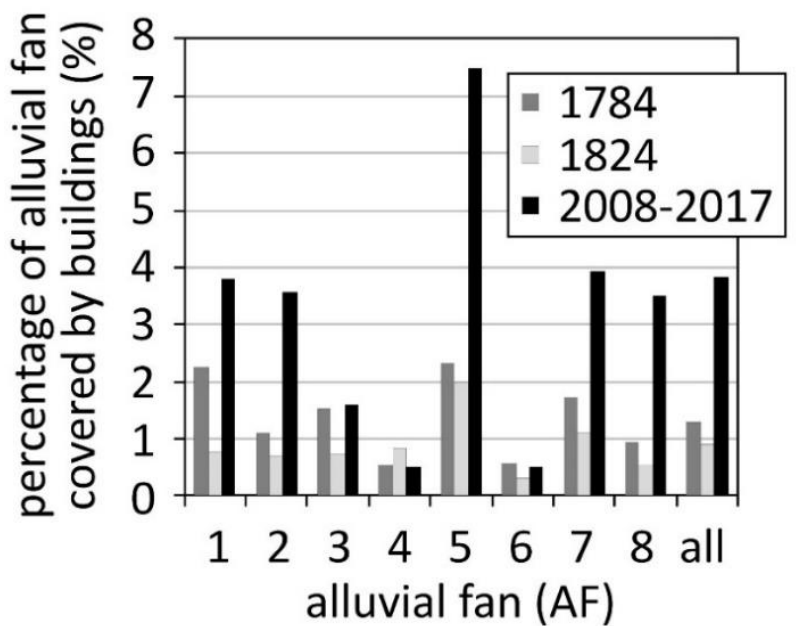

Figure 8 Relative shares of areas covered by buildings distinguished for each of the eight studied alluvial fans and the mean for the three periods for 1784, 1824 and 2008-2017. 


\subsection{Demographic development 1784-2019}

Figure 9 depicts the population changes in the Admont Valley area since 1869 considering also the two communities Ardning (in the west) and Admont separately. For Admont, the c.150 inhabitants of the outside the study area located cadastral commune Johnsbach are included. In 1869 some 4,500 people lived in the Admont Valley and in Johnsbach. The number of people linearly increased until 1934 with a peak in 1939 (possibly related to WW2). Afterwards and until 2001 the number of inhabitants was only slightly increasing. Between 2011 and 2019 the population was rather stable with about 6,200 inhabitants. No accurate data regarding number of inhabitants in the study area were available from earlier times. However, if we extrapolate the population evolution linearly further back in time, we could assume c. 3,500 people in 1824 and c. 2,800 in 1784.

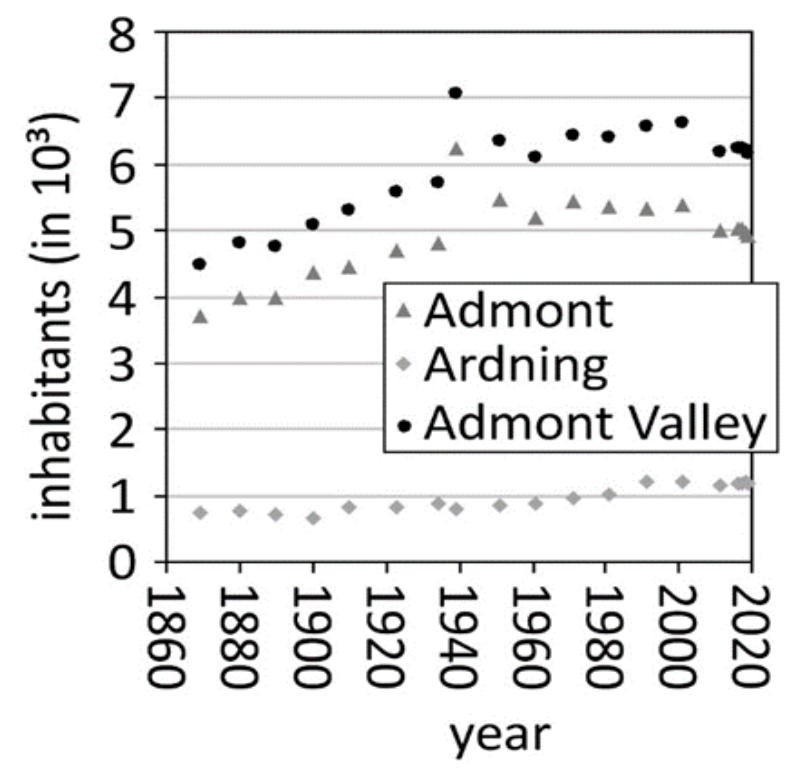

Figure 9 Evolution of the population of the Admont Valley (including the cadastral commune Johnsbach with c.150 inhabitants in 2019) between 1869 and 2019. For data source see text.

\section{Discussion}

\subsection{Building evolution since 1784 at the studied alluvial fans}

Our analyses regarding building evolution between 1784 and present at eight different alluvial fans in the Admont valley revealed a substantial increase in the number of buildings and in the spatial extent of build-up land. However, two main problems occurred in the mapping procedure of the 1784-dataset limiting the meaningfulness of the oldest dataset substantially. First, due to the general distortion of the historic map it was not possible to superimpose in a geometrically satisfying manner the historic map over the present-day data. Mólnar et al. (2014) concluded that georeferencing is well feasible with a remaining error is in the order of 100 $200 \mathrm{~m}$. Furthermore, they point out that further refinement is possible using a rather dense ground control point network (GCP). However, in case of missing candidates for GCP on the original map, this is simply not possible.

This uncertainty implies that buildings that were located at one of the alluvial fans were not accounted for as such and vice-versa. In a geometric context this means inaccurate data. Second, due to the scale of $1: 28,800$ of the original maps, most of the houses and buildings were cartographically presented in a generalized manner such as depicted in Figure 5a for Admont (AF5) or 6a for Hall (AF8). This generalisation gets also evident when we look on the calculated area values for houses for 1784 (e.g., mean $1,074 \mathrm{~m}^{2}$ ) in relation to the two later stages (164 $\mathrm{m}^{2}$ for $1824 ; 179 \mathrm{~m}^{2}$ for 2008-2017). Thus, the cartographic representation of the conditions in 1784 is not only inaccurate but also not precise. This implies that the 1784-cartographic representation is certainly of high value for describing general patterns of buildings and in particular settlement distributions, but it is not feasible at all to compare the areal data calculated for 1784 with those for 1824 or later.

The cadastral land register of Francis I, dating to 1824 in the Admont Valley, provides a substantially different picture. The cadastral land register is the result of detailed geodetic and cartographic work accomplished over a 44-year period and covering an area of $670,000 \mathrm{~km}^{2}$ (Fuhrmann, 2007). The 1824 data in the Admont Valley are accurate and precise in terms of geometry and localization, and surely comparable to the ALS-based building data of 2008-2017. This is for instance illustrated in Figure 5 where the geometry of the Admont Abbey is shown for 1824 (b) and 2008-2017 (c). The church and 
most of the wings of the building complex have identical or only slightly different plan views in both periods. However, as visible in the central part of the abbey, several buildings are missing today. This loss in build-up area is attributed to a big fire in 1865 destroying particularly the central wings of the building complex (List, 1984) reducing the size of the building complex from $14,977 \mathrm{~m}^{2}$ in 1824 to $13,105 \mathrm{~m}^{2}$ today.

The ALS-based building distribution mapped at a scale 1:500 (Land Steiermark 2019) is also regarded as accurate and precise data. The thus feasible comparison of the two latter data sets show a 3.9-fold increase in the number of buildings from 911 to 3554 in c.190 years. In the same time, the entire population in the Admont Valley increased from c. 3500 to c.6200, i.e. only 1.8 times. This difference in multiplications of buildings and population between the two stages implies inhabitants per house also attributed to substantial socio-economic changes during the last 190 years.

\subsection{Relationship between hazard-zones, dam- aging events and building evolution}

The comparison of official hazard-zone plans with our mapping results (1784 and 1824) and existing building distribution data (2008-2017) show that a significant amount of buildings are located partly or entirely in yellow (moderate-risk) and red (high-risk) hazard zones. Whereas the analysis results for the 1784 data (Table 3a) are only of limited meaningfulness due to inaccurate and unprecise data, the results for the latter to stages (Table 3b, c) are of great significance. At present, $11.9 \%$ of all 3,554 buildings are partly or entirely in a red hazard zone. $26.4 \%$ are partly or entirely in a yellow hazard zone. Some 190 years earlier (and with 911 buildings), these percentage values would have been even higher with $25.6 \%$ for red and $36.8 \%$ for yellow hazard zones. These values clearly show that despite a tremendous increase in buildings at the eight alluvial fans (cf. Fig. $5 c, 6 c)$, the proportion of buildings exposed to torrents-related natural hazards significantly decreased by $10.4 \%$ for yellow and by $13.7 \%$ for red zone areas.
The documented damaging events at the eight studied alluvial fans highlight the importance of floods (32.2\% of all events) and fluvial sediment transport events with notable but $<20 \%$ volumetric debris content (44.1\%). Debris flows were only $11.9 \%$ of all documented damaging events since 1851. The alluvial fan AF2 was very much affected by damaging processes in the past which is also considered in the hazard zone plan (Fig. 3a). $57.4 \%$ of the entire alluvial fan is still in a high-risk (red) to moderate-risk (yellow) zone, despite the fact that protection constructions were installed in several of the torrents (Fig. 3a) that flow onto the large alluvial fan. This potential threat to floods and flood-related geomorphic processes at AF2 had only to a limited extent an impact on the building evolution at this fan. $72.5 \%$ of all buildings at AF2 are entirely or partly in the yellow zone. Comparable high values for yellow zones were revealed for AF3 and AF7. Regarding red zones, $15-30 \%$ of all buildings at AF2, AF7, AF4, and AF3 are partly or entirely in such high-risk zones.

The fact that so many present buildings are in high- and moderate-risk areas is attributed to the age differences between the buildings and hazard zonation plans in the Admont Valley. A total of 102 hazard zones were identified at the eight alluvial fans dating to different years: 42 dates to 1981, 33 to 1998, 21 to 2014, and 6 to 2015 (Federal Ministry for Sustainability and Tourism, 2017). These age dates illustrate that it is quite normal - in the Admont Valley but also all-over alpine Austria - that many hazard zonation plans are younger (e.g. central part of Admont; Fig. 5) compared to the buildings within them. New buildings at yellow zone areas are possible, but restricted and with building obligations (e.g. at AF2).

\subsection{The wider significance of the present study}

What is now a wider significance of such a study in more regional to national context? As stated in the material and methods section the existence and the increasing availably of historic maps allow longerterm studies on settlement and building evolution even at a landform-scale. The spatial extent of the First Military Survey of the Habsburg Empire excluding present-day Belgium covers some 640,000 
$\mathrm{km}^{2}$. This is obviously a huge part of central and Eastern Europe (Fig. 2a). The spatial extent of the cadastral land register of Francis $I$ is similar with $670,000 \mathrm{~km}^{2}$ (Fig. 2b; Fuhrmann, 2007). The considered areas in both map products are not the same. However, for many areas in present-day Czech Republic, Slovakia, Hungary, Ukraine, Romania, Poland, Serbia, Croatia, Slovenia and Italy digital historic maps are available for similar studies.

Regarding landform-relevance, particularly in alpine areas alluvial fans played a major role for settlement and housing establishment in the past and even today. As we showed with the example Admont Valley $\left(236.1 \mathrm{~km}^{2}\right)$, by far most present-day buildings (69.2\%) are located at only eight alluvial fans (total area $16.6 \mathrm{~km}^{2}$ ). Topographically comparable conditions in other areas of the former Habsburg Empire (e.g. Carpathians, Dinaric Alps) might allow alluvial fan-settlement evolution studies using the Habsburg-data. Furthermore, such data might contribute to understand long-term man-landscape interactions at landform scale (Zygmunt, 2009). Furthermore, also other specific landforms could be assessed using historical data regarding their settlement evolution significance as for instance shown for a depression basin in eastern Romania (ChirilăAcatrinei, 2015) or the urban development in Sibiu, Central Romania (Costea, 2016). Thus, analysing historical maps that are relatively accurate and precise have a high potential in historio-geomorphological research.

\section{Conclusions}

From this study, the following main conclusions can be drawn:

- Historical maps at large scale and as georeferenced products are increasingly available for geographical and historical research question. In this study we used (and partly re-georeferenced) historical maps from 1784 (at scale 1:28,800) and 1824 $(1: 2,880)$ from an alpine valley (Admont Valley) and combined this information with geomorphic (landform distribution), geomorphodynamic (documented damaging events at torrents) and spatial planning (hazard zonation maps) data.
- We showed that the used map product from the $18^{\text {th }}$ century is useful for general settlement evolution assessments. However, a detailed spatial analysis and a comparison with present-day data (in terms of buildings but also hazard zonation plans) at a building-scale is not feasible, due to the distortion of the map related to triangulation and projection problems and the generalisation of objects. This implies geometrically inaccurate and unprecise data.

- The analysis and comparison of the large scale, accurate and also precise (horizontal accuracy in the order of $10 \mathrm{~m}$ ) building data from the year 1824 with present-day data (2008-2017) revealed spatial and socio-economic insight into the population and building evolution over a 190-year period at eight alluvial fans. Whereas the number of buildings increased 3.9 times, the population only grew 1.8 times. Despite a tremendous increase in buildings (911 in 1824; 3,554 in 2008-2017), the proportion of buildings exposed to torrents-related natural hazards significantly decreased by $10.4 \%$ for yellow (moderate-risk) and by $13.7 \%$ for red (high-risk) zones.

- The large spatial extent of the used historical data with $640,000 \mathrm{~km}^{2}$ (excluding present-day Belgium) for the First Military Survey of the Habsburg Empire dating to $1764-1787$ and $670,000 \mathrm{~km}^{2}$ for the cadastral land register of Francis I dating to 1817-1861 implies that similar historiogeomorphological studies as presented here might be accomplished in other countries in central and eastern Europe.

\section{Acknowledgements}

The Austrian Federal Service for Torrent and Avalanche Control - particularly Markus Mayerl - is kindly acknowledged for providing data of natural hazard events which happened between 1851 and 2017 and for information regarding technical control measures against debris flows and floods in the Admont Valley. The Geographical Information Service of the Federal Government of Styria (GIS-Steiermark) is very much thanked for providing a digital terrain data. The authors acknowledge the financial support by the University of Graz. 


\section{References}

Auer M, Bleibinhaus F, Tschurtschenthaler M, Unterwurzacher M. 2013. Municipium Claudium Aguntum Georadar-Messungen in geologisch schwierigem Terrain. Jahreshefte des Österreichischen Archäologischen Institutes, 82: 7-21.

Büchner KH. 1974. Ergebnisse einer geologischen Neuaufnahme der nördlichen und südlichen Gesäuseberge (Ober-Steiermark, Österreich). Mitteilungen der Gesellschaft der Geologie- und Bergbaustudenten in Österreich, 22: 71-95.

Chirilă-Acatrinei A. 2015. Interactions between human settlements and Geomorphology in Huși Depression, NE Romania. Studia Ubb Geographia, LX 2: 17-26.

Costea M. 2016. Landforms and urban development. An example of urban geomorphology from Romania (Sibiu, Transylvania) January 2016. Brukenthal. Acta Musei, 11(3): 491-506.

Fuhrmann S. 2007. Digitale Historische Geobasisdaten im Bundesamt für Eich- und Vermessungswesen (BEV) Die Urmappe des Franziszeischen Kataster. Vermessung \& Geoinformation, 1: 24-35.

Hofstätter E. 1989. Beiträge zur Geschichte der österreichischen Landesaufnahmen: Ein Überblick der topographischen Aufnahmeverfahren, deren Ursprünge, ihrer Entwicklungen und Organisationsformen der vier österreichischen Landesaufnahmen. 1. Teil. Bundesamt für Eich- u. Vermessungswesen, Vienna, $196 \mathrm{p}$.

Kellerer-Pirklbauer A, Proske T, Untersweg T. 2004. Darstellung der Talbodenbereiche des Steirischen Ennstals. Project Report. Institut für Digitale Bildverarbeitung, Joanneum Research, Graz, 50 p.

Krause A. 1966. Admont und das Gesäuse in Geschichte und Sage - 2. Auflage, Oberösterreichischer Landesverlag, Linz, 144 p.

Land Steiermark. 2019. Katalog ALS Gebäudemaske (2008-2012) Steiermark (Extraction of buildings from Airborne Laserscanner data). CC-BY-4.0: Land Steiermark - data.steiermark.gv.at [last access 02 September 2019].

List R. 1974. Stift Admont 1074 - 1974: Festschrift zur Neunhundertjahrfeier. Ried im Innkreis: OÖ. Landesverlag, $559 \mathrm{p}$.

Mólnar G, Timár G, Biszak E. 2014. Can the First Military Survey maps of the Habsburg Empire (1763-1790) be georeferenced by an accuracy of 200 meters? 9th International Workshop on Digital Approaches to Car- tographic Heritage, Budapest, 4-5 September 2014, 1-7. DOI: 10.13140/2.1.1447.8724

Patzelt G. 1987. Untersuchungen zur nacheiszeitlichen Schwemmkegel- und Talentwicklung in Tirol. 1. Teil: Das Inntal zwischen Mötz und Wattens. Veröffentlichung des Tiroler Museum Ferdinandeum, 67: 93-123.

Patzelt G. 1994. Holocene development of alluvial fans and the floor of the Inn Valley. Mountain Research and Development, 14 (4): 283-284.

Reismann B, Wiedner J, Bergmann H, Kainz H, Kauch P. 2015. Wasserwirtschaft in der Steiermark - Geschichte und Gegenwart. Graz. Steiermärkisches Landesarchiv, Graz, 504 p.

Slaymaker O, Embleton-Hamann C. 2009. Mountains. In: Slaymaker O, Spencer T, Embleton-Hamann C (eds.): Geomorphology and Global Environmental Change. Cambridge University Press, Cambridge, 37-70. DOI: https://doi.org/10.1017/CBO9780511627057.003, pp 37-70.

Statistik Austria. 2019. Population evolution of the two communities Admont and Ardnig between 1869 and 2018. https://www.statistik.at/blickgem/index.jsp [last access 02 September 2019].

Unterweger O. 2018. Zur Geomorphologie des Debantbaches und dessen Einfluss auf das Stadtgebiet von Aguntum. In: Auer M, Stadler H (eds.): Von Aguntum zum Alkuser See - Zur römischen Geschichte der Siedlungskammer Osttirol. Harrassowitz Verlag, Wiesbaden, 167-172.

Wichner J. 1880. Geschichte des Benediktiner-Stiftes Admont, 4: Vom Jahre 1466 bis auf die neueste Zeit. Festgabe zur Feier der Erinnerung an den 1400 jährigen Geburtstag des hl. Benedikt. Graz: Selbstverlag des Verfassers, 343 p.

WLK. 2019. WLK.Digital.Ereigniskataster - Das Ereignisportal des digitalen Wildbach - und Lawinenkatasters des Forsttechnischen Dienstes für Wildbach- und Lawinenverbauung. [online] Forsttechnischen Dienstes für Wildbach- und Lawinenverbauung. Available from: https://naturgefahren.die-wildbach.at/V3/index.aspx [last access 02 February 2019].

Zanesco A, Nicolussi K, Patzelt G. 2008. Die Überschwemmung der Unterstadt von Hall im Jahre 1275. In: Zanesco A, Schmitz-Esser R. (eds.): Forum Hall in Tirol, Neues zur Geschichte der Stadt, Hall, 40-53.

Zygmunt E. 2009. Alluvial fans as an effect of long-term man-landscape interactions and moist climatic conditions: A case study from the Glubczyce Plateau, SW Poland. Geomorphology, 108: 58-70. 